\title{
ASSESSMENT OF CORE GROUP RICE (Oryza sativa L.) LANDRACES OF CHHATTISGARH FOR QUALITY ATTRIBUTES
}

\author{
Suman Rawte*, Ritu R. Saxena, Saurabh Kumar Kulhariya \\ Department of Genetics and Plant Breeding, Agricultural Engineering and Technology and Research Station College of Agriculture, IGKV, Raipur (CG)
}

Received - March 03, 2020; Revision - June 03, 2020; Accepted - June 22, 2020

Available Online - June 25, 2020

DOI: http://dx.doi.org/10.18006/2020.8(3).310.319

\section{KEYWORDS \\ Rice \\ Quality \\ Germplasm \\ Amylose \\ Gel Consistency}

\begin{abstract}
The investigation was carried out to estimate the components of genetic variability and associated statistical parameters for grain quality traits of 95 indigenous rice landraces along with 5 checks of Chhattisgarh, India. Substantial genetic variability among the all genotypes was observed for the characteristics under study. The investigated traits showed a wide range of variability. Traits such as weight of thousand grains, grain length, head rice recovery, amylose content and gel consistency revealed high value of genetic parameters also the head rice recovery shows positive and significant association with hulling percent and milling percentage. Results of study revealed that selected genotypes can be used as breeding material for quality improvement in rice.
\end{abstract}

* Corresponding author

E-mail: suman.rawte@gmail.com (Suman Rawte)

Peer review under responsibility of Journal of Experimental Biology and Agricultural Sciences.

Production and Hosting by Horizon Publisher India [HPI] (http://www.horizonpublisherindia.in/).

All rights reserved.
All the articles published by Journal of Experimental Biology and Agricultural Sciences are licensed under a Creative Commons Attribution-NonCommercial 4.0 International License Based on a work at www.jebas.org.

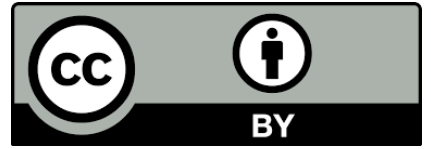




\section{Introduction}

Rice (Oryza sativa L.) is the most important food crop in the world, as it is a staple food for more than half of the world's population. Rice eating quality largely determines its market price and consumer acceptance, because consumers pay particular attention to high eating quality (Anacleto et al., 2015). Rice landraces, local varieties, indigenous lines play a pivotal role for food nutritional and health security besides resistance to diseases and pests and resilience to climate changes which is needed for the survival of human civilization on earth. Rice is food grain crop of global importance with special preference in Asian countries. This diversity provides further genetic improvement along with nutrient enrichment. Nutritive assessment, physico-chemical variability in the rice germplasm and their further utilization in the breeding programme is the present need to combat hidden hunger.

Rice quality remains in the eye of the consumer and since rice consumption is entrenched in a historical, geographical, and sociocultural context (Cuevas et al., 2017), a universal, intercultural idea of rice quality is required. Understanding how the market and the industry notice rice and distinguish it into quality classes could contribute to more efficient, demand-driven, and sustainable rice (My et al., 2018).

Thus, in past few decades the trend of keeping rice grain quality improvement as a major objective in every rice improvement program has rapidly increased among the rice breeders. Improving the rice grain quality shall involve the screening of the available germplasm for quality traits. Selection of rice variety depends on their physical appearances like size and shape. This is due to structure and arrangement of cells in endosperm which are primarily accountable to bring some changes in physical form of rice. If rice has increased girth, it may not be appropriate, while some rice such as basmati shows high kernel elongation which is desirable and appropriate for consumer acceptance. Kernel length also depends on ageing time, gelatinization, hydration etc. (Jamuna et al., 2019).

Thus, the present investigation was intended to analyse local landraces of Chhattisgarh along with some checks of rice maintained at the Indira Gandhi Krishi Vishwvidyalaya, Raipur for grain quality traits.

\section{Materials and Methods}

\subsection{Plant Materials}

The experimental material comprises total of 100 genotypes including 95 traditional landraces and five local varieties of rice from Chhattisgarh, India (Table 1). A total of 400 rice landraces and local varieties were collected from different parts of Chhattisgarh and were grown at research field, IGKV, Raipur during Kharif 2017 by following the Randomized block design. A core set of 95 rice landraces was constructed by selecting superior genotypes based on their grain yield and attributing traits from

Table 1 List of hundred rice genotypes used in quality analysis

\begin{tabular}{|clrlrlll|}
\hline S. No. & Name & S. No. & Name & S. No. & Name & S. No. & Name \\
\hline 1 & Bagri & 26 & Kanak & 51 & Ama jhopa & 76 & Ram Jira \\
\hline 2 & Hardi chudi & 27 & Mehapal & 52 & Koudi dhull & 77 & Bhejari \\
\hline 3 & Koto & 28 & Tebaroo Mundaria & 53 & Sau pankhi & 78 & Danwar \\
\hline 4 & Kotte (II) & 29 & Padari dhan IV & 54 & Dokra Dokri & 79 & Karhani \\
\hline 5 & Satha dhan & 30 & Budhiya wako & 55 & Parmal & 80 & Chiko \\
\hline 6 & Karhani & 31 & BD kankari bija & 56 & Dokrae mechha & 81 & Farsa Phool \\
\hline 7 & Kohaka & 32 & Bawati chudi & 57 & Roti & 82 & Baila Aankhi \\
\hline 8 & Luchai(A) & 33 & Kalajira & 58 & Khatia pati & 83 & Bokra Mundi \\
\hline 9 & Angur Guchcha & 34 & Sonapan & 59 & Hathi panjra & 84 & Hunuman Langur \\
\hline 10 & Basigal(ii) & 35 & Bakal & 60 & CR-1014 & 85 & Jal Ponga \\
\hline 11 & Bhejari & 36 & Cross 116 & 61 & Elayachi & 86 & Banda \\
\hline 12 & Bhulau & 37 & Deshi lal dhan & 62 & Tulsi manjari & 87 & Lanji \\
\hline 13 & Bodi & 38 & IR 42253 & 63 & Shyam jira-1 & 88 & Raja Bangla \\
\hline 14 & Peelee Luchai & 39 & Lalmati & 64 & Lokti Machhi & 89 & Bhainsa Mundariya \\
\hline 15 & Tulsi Phool & 40 & Laloo-14 & 65 & Muni Bhog & 90 & Nariyal Chudi \\
\hline 16 & Silipat & 41 & Jhitpiti & 66 & Jou Phool & 91 & Kating \\
\hline 17 & Unknown & 42 & WR99 & 67 & Bhainsa Punchhi & 92 & Bhamasur \\
\hline 18 & Ama Dhul & 43 & E-1702 & 68 & Bhanta Phool-1 & 93 & Paltu \\
\hline 19 & Baisur & 44 & Chapti gurmatia & 69 & Lahsun Bhog & 94 & Sindur senga \\
\hline 20 & Bylao & 45 & Elayachi & 70 & Ichchawati & 95 & Swarna \\
\hline 21 & Asam Chudi & 46 & Bisni-I & 71 & Laxmi Bhog & 96 & MTU-1010 \\
\hline 22 & Bhaniya & 47 & Moroberekan & 72 & Tulsi Mala & 97 & IR64 \\
\hline 23 & Farsa Phool & 48 & Nagina-22 & 73 & Jou Phool-2 & 98 & R-RF-75 \\
\hline 24 & Jalle & 49 & R-RF-75 & 74 & Jeera Phool & 99 & IGKV R1 \\
\hline 25 & Kanak Jira & 50 & Kadam Phool & 75 & Tulsi Mongra & 100 & Danteshwari \\
\hline & & & & & \\
\hline
\end{tabular}

Journal of Experimental Biology and Agricultural Sciences 
these 400 genotypes. All 95 landraces were cleaned properly, dried in hot air oven up to $12-14 \%$ moisture content and kept at room temperature for four months then used for grain quality parameter estimation at R.H. Richharia Rice Research Laboratory, Department of Genetics and Plant Breeding, IGKV, Raipur (CG), India. In this investigation, grain quality parameters of each rice samples were analyzed in duplicates.

\subsection{Physical parameters of rice grains}

All the standard protocol according to Indian Institute of Rice Research, Hyderabad, India (formerly, Directorate of Rice Research) was followed for estimating the grain quality parameters (DRR, 2014).

\subsubsection{Brown rice length and breadth $(\mathrm{L} / \mathrm{B})$ ratio}

Brown rice length and breadth of 10 random samples of whole rice grains from each genotype were measured manually by using millimetre scale and graph. Average length and breadth of 10 samples were used for $\mathrm{L} / \mathrm{B}$ ratio calculation and further analysis.

\subsubsection{Brown rice recovery percent (hulling percent)}

About 100 gram of rough rice samples were hulled by a single pass through a standard rubber roll huller (Satake Engineering Co. Ltd. Tokyo, Japan) to produce brown rice (decorticated rice). The brown rice was then weighed and used for calculation of hulling percentage based on initial weight of rough rice as; hulling percent $=$ (weight of hulled rice/ weight of rough rice) X100 (DRR, 2014).

\subsubsection{Milled rice recovery percent (milling percent)}

Hulled brown rice was then used for milling up to $5 \%$ by using a McGill No. 2 miller (Rapsilver Supply Co. Inc., Brookshire, TX). The generated milled rice was weighed and used for milling percent calculation based on initial weight of rough rice as; milling percent = (weight of milled rice/ weight of rough rice) X100 (DRR, 2014).

\subsubsection{Head rice recovery percent (HRR percent)}

Milled rice kernels were separated into head rice and broken kernel fractions with different sized separator/ sieves. Full kernel and $3 / 4$ size kernels were considered as head rice and weighed for calculating HRR percentage. Head rice recovery percentage was calculated as; head rice recovery percent $=($ weight of full kernel and $3 / 4$ sized kernel/ weight of rough rice) X 100 (DRR, 2014).

\subsection{Grain physico-chemical and cooking parameters}

\subsubsection{Elongation Ratio}

Elongation ratio of cooked kernels was determined by dividing the length of cooked kernel to length of uncooked kernel.
2.3.2 Alkali Spreading Value and Gelatinization temperature (GT)

Alkali Spreading Value and gelatinization temperature was assessed using standard alkali digestion and spreading scores (Little et al., 1958). Six whole grains from each of the genotypes were placed in plastic Petridish containing $10 \mathrm{ml} 1.7 \% \mathrm{KOH}$. The arrangements of grains were in such a way that they were not in contact with each other. All the petri dishes were properly covered and incubated at $30^{\circ} \mathrm{C}$ for 23 hours. Scoring was based on visual appearance and disintegration of all the six endosperm of each genotype.

\subsubsection{Gel consistency (GC)}

Polished rice of each genotype was powdered by using mortar and pestle followed by sieved with $1 \mathrm{~mm}$ sieve. In long test tube $(2 \times 19.5 \mathrm{~cm}), 100 \mathrm{mg}$ of rice flour was taken followed by adding of $0.2 \mathrm{ml}$ of ethanol containing $0.25 \%$ thymol blue. Thereafter, $2.0 \mathrm{ml}$ of $2.8 \mathrm{~g} \mathrm{KOH}$ in $250 \mathrm{ml}$ distilled water was added into each tube and mixed properly by using vortexer. All the samples were kept in hot water bath for $8 \mathrm{~min}$ then cooled for 5 minutes. All the samples were vortexed again and kept in ice bath for $20 \mathrm{~min}$. Later on, all the tubes were taken out and laid horizontally on laminated graph paper for one hour to take the measurement (DRR, 2014).

\subsubsection{Amylose content (AC)}

Amylose content of each landrace was estimated by following the method of Juliano (1971). 100mg rice flour was taken into volumetric flask and added $1 \mathrm{ml}$ ethanol (95\%) with $9 \mathrm{ml}$ of sodium hydroxide $(1 \mathrm{~N})$. The samples were kept on a boiling water bath followed by cooling for 10 minutes at room temperature. Final volume of $100 \mathrm{ml}$ was made by adding distil water. Thereafter, $5 \mathrm{ml}$ solution was pipetted out from $100 \mathrm{ml}$ stock solution and added $1 \mathrm{ml}$ of acetic acid $(1 \mathrm{~N})$ and $2 \mathrm{ml}$ of freshly prepared iodine solution. Solutions were shaken properly and kept at dark place for 20 minutes and determine the absorbance at $620 \mathrm{~nm}$ using a UVVis spectrophotometer (Jasco, Cambridge, UK).

\subsection{Statistical analysis:}

Descriptive statistics for all the traits and histogram were made by using XLSTAT v18.07. Analysis of variance (One way ANOVA) was calculated by using OPSTAT software following the suggested formula of Panse \& Sukhatme (1967). Method suggested by Burton (1952) was followed for calculation of genotypic coefficient of variation (GCV) and phenotypic coefficient of variation (PCV). Broad sense heritability $\left(\mathrm{h}^{2}\right)$ was calculated as per method suggested by Hanson et al. (1956). Similarly, method suggested by Johnson et al. (1955) was used for the calculation of genetic advance (GA). GCV, PCV, heritability and genetic advance were analyzed manually by MS-Excel-2013 by following the above mentioned methods. 
Table 2 ANOVA table for quality traits

\begin{tabular}{|c|c|c|c|c|c|c|c|c|c|c|c|}
\hline Source & DF & GL & TGW & GW & L: BRR & DGL & DGW & DL: BR & MGL & MGW & ML: BR \\
\hline Treatment & 99 & $6.20 * *$ & $136.4^{* *}$ & $0.41 * *$ & $1.02 * *$ & $2.34 * *$ & $0.15^{* *}$ & $0.52 * *$ & $1.92 * *$ & $0.12 * *$ & $0.48 * *$ \\
\hline Replication & 1 & $0.004 * *$ & 0.24 & 0.00 & 0.00 & $0.03 * *$ & $0.59^{* *}$ & $0.56^{* *}$ & $0.10^{* *}$ & $0.11 * *$ & $0.04 *$ \\
\hline Error & 99 & 0.00 & 0.09 & 0.05 & 0.03 & 0.00 & 0.05 & 0.01 & 0.00 & 0.00 & 0.01 \\
\hline Total & 199 & & & & & & & & & & \\
\hline \multicolumn{12}{|c|}{$*$ and $* *$ significant at 5 and $1 \%$ probability level } \\
\hline Source & $\mathrm{DF}$ & HP & MP & AMYLOSE & HRR & CGL & CGW & CLBR & ER & EI & $\mathrm{GC}$ \\
\hline Treatment & 99 & $242.2^{* *}$ & $242.0^{* *}$ & $68.83^{* *}$ & $533.6^{* *}$ & $3.86^{* *}$ & $0.25^{* *}$ & $0.45^{* *}$ & $0.12 * *$ & $0.094 * *$ & $778.0^{* *}$ \\
\hline Replication & 1 & $92.46^{* *}$ & $40.10^{* *}$ & 7.34 & 7.58 & 0.03 & $0.9^{* *}$ & $0.66^{* *}$ & 0.00 & $0.06 * *$ & 0.40 \\
\hline Error & 99 & 0.71 & 0.31 & 7.34 & 6.33 & 0.02 & 0.01 & 0.01 & 0.00 & 0.00 & 0.42 \\
\hline Total & 199 & & & & & & & & & & \\
\hline
\end{tabular}

\section{Results and Discussion}

\subsection{Analysis of Variance (ANOVA)}

The analysis of variance (ANOVA) revealed the presence of highly significant differences among all the hundred rice lines for all the grain quality characters (Table 2). This specifies the existence of generous amount of variability among the materials used for studied characters. "Coefficient of variation is simply a measure of dispersion of the variable". In present study, CV ranges from $11.19 \%$ for Grain width after milling to $39.52 \%$ for head rice recovery. "Coefficient of variation" was observed higher for head rice recovery (39.52\%) followed by thousand grain weight (36.13\%) and amylose content (30.69\%). Results describe that overall "high coefficient of variation" was present for all the characters under study. The presence of a wide range of variability might be due to various sources of the accessions having high "natural recombination and mutations" that has impact over decades in these lines. Thus, there is a noble chance to select better parental types improving the rice grain quality characters. The results were similar with the finding of Dhanwani et al. (2013); Devi et al. (2016) and Devi et al. (2017). Plant breeder uses selection for improving the interested traits of crop by management of available genetic variability and usually landraces are known to have larger range of variability (Kiani \& Nematzadeh, 2012; Abdala et al., 2016) Present study shows the possibility of effective selection for enhancement of rice grain quality in subsequent segregating populations for these genotypes.

\subsection{Genetic Variability Parameters}

\subsubsection{Genotypic coefficient of variation (GCV) and phenotypic coefficient of variation (PCV)}

The magnitude of coefficient of variation was categorized as high (> $20 \%$ ), moderate $(10-20 \%)$ and low $(<10 \%)$. The high phenotypic coefficient of variation (PCV) and genotypic coefficient of variation (GCV) was seen for head rice recovery $(39.76 \%$ and $39.29 \%)$ and thousand grain weight $(36.14 \%$ and $36.11 \%)$ while the elongation index $(19.99 \%$ and $19.29 \%)$, decorticated length breadth ratio (18.79\% and $18.36 \%)$, milled grain length(18.56\% and $18.53 \%)$, kernel L/B ratio after cooking (18.57\% and $18.12 \%)$, grain length after cooking (18.09\% and $17.99 \%)$, kernel breadth $(17.14 \%$ and $15.32 \%)$, kernel L/B ratio $(23.92 \%$ and $23.31 \%)$, kernel breadth after cooking (12.21\% and $11.49 \%)$, elongation ratio $(16.65 \%$ and $16.53 \%)$, hulling percent (14.55\% and $14.50 \%)$ and decorticated grain width (12.17\% and $11.49 \%)$, milled grain width $(11.40 \%$ and $10.97)$, decorticated grain length (16.95\% and $16.94 \%)$ and milling percent (16.21 and 16.19\%) were showed intermediate PCV and GCV. Gelatinization temperature $(8.17 \%$ and $8.17 \%)$ showed slightly lower PCV and GCV based on the scale (Table 3). "Higher and intermediate value of GCV gives idea for selection of trait with significant improvement. However estimation of total heritable variation based on GCV only could not give significant output (Roychowdhury \& Tah, 2011). Undeniably the differences between GCV and PCV revealed clearly that environment played an important role in expression of these traits. On the contrary the narrow differences was found between PCV and GCV in thousand grain weight, grain length, length breadth ratio, decorticated grain length, milled grain length, hulling and milling percentage, head rice recovery, gel consistency, elongation ratio and elongation index signifies the low sensitivity of these traits to environmental effects.Related results were also perceived by Babu et al. (2012) and Maneerattanarungroj et al. (2015).

\subsubsection{Broad sense heritability}

Heritability $\left(\mathrm{h}^{2}\right)$ estimates were interpreted as low $(<30 \%)$, medium $(31 \%-70 \%)$ and high $(>70 \%)$ as per the classification of Johnson et 
al. (1955). In the present investigation all the grain quality characters showed high heritability (broad sense). Highest broad sense heritability unveiled for grain length $(99.99 \%)$ followed by gel consistency (99.89\%), decorticated grain length (99.88\%), milling percent (99.74\%), kernel length after cooking (98.96\%) and thousand grain weight $(99.88 \%$ ) (Table 3$)$. High heritability values specify that the characters under study are less influenced by environment. Aforesaid traits shows high heritability that indicates these traits are heritable in nature in future generation hence, high heritability in broad sense values indicate that the characters under study are less influenced by environment in their expression. Therefore, the rice breeders may make superior genotypes selection based on phenotypic performance for these traits. Similar results have been also reported by Rathi et al. (2010) and Babu et al. (2012).

\subsubsection{Genetic advance as percent of mean}

The assessments of GA as percent of mean give more consistent information regarding the effectiveness of selection in improving the characters. GA indicates the improvement in the genotypic value of the new population over the original population. Johnson et al. (1955) categorized the GA as percent of mean as high $(>20 \%)$, moderate $(10-20 \%)$ and low $(<10 \%)$. All the studied grain quality traits were revealed high estimate of GA as percent of mean except for gelatinization temperature (16.83\%) which showed moderate GA as percent mean. Highest GA as percent mean was observed in head rice recovery $(79.98 \%)$ followed by thousand grain weight $(74.35 \%)$, kernel length after milling $(38.10 \%)$ and grain length after cooking $(36.87 \%)$ (Table 3 ). Therefore, selection based on the aforesaid traits with high and moderate genetic advance as percent of mean, result in the improvement of the genotypes for the traits. Similar result was also reported by Rathi et al. (2010); Babu et al. (2012) and Suman et al. (2020).

High heritability with high GA as percent mean was seen for all the grain quality characters except for gelatinization temperature which specified that expression of these traits are less influenced by

Table 3 Variability and Genetic parameters of Quality traits

\begin{tabular}{|c|c|c|c|c|c|c|c|c|c|}
\hline Traits & Mean & Range & SE & SD & CV (\%) & PCV & $\mathrm{GCV}$ & $h^{2}$ & Expected GA \\
\hline TGW & 22.86 & $8.7-47.4$ & 0.83 & 8.26 & 36.13 & 36.14 & 36.11 & 99.88 & 74.35 \\
\hline GL & 8.30 & $4.84-12.66$ & 0.18 & 1.76 & 21.23 & 21.23 & 21.23 & 99.99 & 43.72 \\
\hline GW & 2.80 & $1.79-3.96$ & 0.05 & 0.45 & 16.26 & 17.14 & 15.32 & 79.86 & 28.20 \\
\hline L: BRR & 3.03 & $1.76-5.42$ & 0.07 & 0.71 & 23.61 & 23.92 & 23.31 & 95.00 & 46.80 \\
\hline DGL & 6.39 & $4-8$ & 0.11 & 1.08 & 16.94 & 16.95 & 16.94 & 99.88 & 34.87 \\
\hline DGW & 2.35 & $1.6-3.0$ & 0.03 & 0.28 & 11.84 & 12.17 & 11.49 & 89.17 & 22.36 \\
\hline DL: BR & 2.75 & $1.57-4.37$ & 0.05 & 0.51 & 18.58 & 18.79 & 18.36 & 95.45 & 36.96 \\
\hline MGL & 5.28 & $3.9-7$ & 0.10 & 0.98 & 18.54 & 18.56 & 18.53 & 99.67 & 38.10 \\
\hline MGW & 2.22 & $1.55-2.7$ & 0.02 & 0.25 & 11.19 & 11.40 & 10.97 & 92.64 & 21.75 \\
\hline MGL: BR & 2.41 & $1.54-3.875$ & 0.05 & 0.49 & 20.56 & 20.72 & 20.39 & 96.92 & 41.36 \\
\hline $\mathrm{HP}$ & 75.77 & $43.45-96.85$ & 1.10 & 11.01 & 14.52 & 14.55 & 14.50 & 99.42 & 29.79 \\
\hline MP & 67.92 & $37.35-90.92$ & 1.10 & 11.00 & 16.20 & 16.21 & 16.19 & 99.74 & 33.30 \\
\hline AMYLOSE & 19.11 & $5.07-40.69$ & 0.59 & 5.87 & 30.69 & 32.29 & 29.01 & 80.72 & 53.69 \\
\hline HRR & 41.33 & $10.16-76.08$ & 1.63 & 16.33 & 39.52 & 39.76 & 39.29 & 97.66 & 79.98 \\
\hline CGL & 7.71 & $5-11$ & 0.14 & 1.39 & 18.04 & 18.09 & 17.99 & 98.96 & 36.87 \\
\hline CGW & 2.99 & $2.2-3.7$ & 0.04 & 0.36 & 11.99 & 12.21 & 11.76 & 92.72 & 23.33 \\
\hline CLBR & 2.60 & $1.47-3.92$ & 0.05 & 0.48 & 18.35 & 18.57 & 18.12 & 95.30 & 36.45 \\
\hline ER & 1.48 & $1-2.21$ & 0.02 & 0.25 & 16.59 & 16.65 & 16.53 & 98.60 & 33.82 \\
\hline EI & 1.11 & $0.58-1.72$ & 0.02 & 0.22 & 19.65 & 19.99 & 19.29 & 93.17 & 38.36 \\
\hline $\mathrm{GC}$ & 92.32 & $28-100$ & 1.97 & 19.72 & 21.37 & 21.37 & 21.36 & 99.89 & 43.98 \\
\hline
\end{tabular}

TGW-Thousand grain weight, GL-Grain length, GW-Grain width, L:BRR-Length breadth ratio, DGL-Decorticated grain length, DGWDecorticated grain weight. DL:BR-Length breadth ratio of decorticated grain, MGL-Milled grain length, MGW-Milled grain weight. MGL:BR-Length breadth ratio of milled grain, HP-Hulling percent, MP-Milling percent, HRR-Head rice recovery, CGL-Cooked grain length, CGW-Cooked grain weight. CLBR-Length breadth ratio of cooked grain, ER-Elongation ratio, EI-Elongation index. 


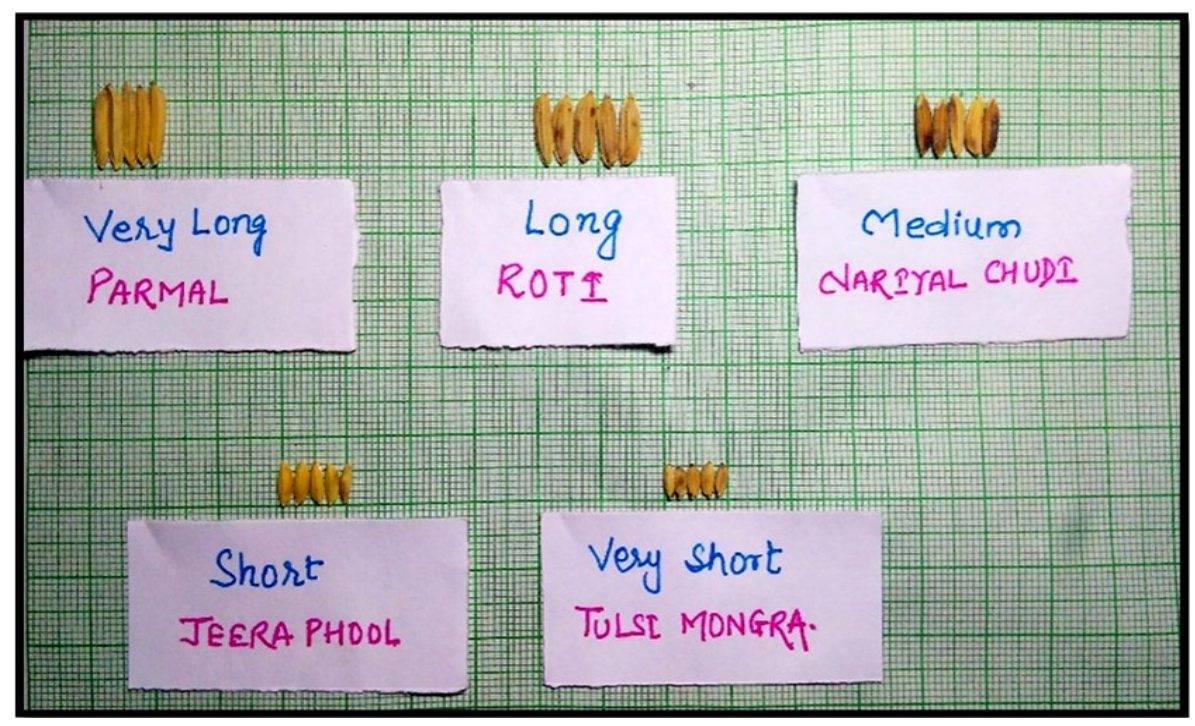

Figure 1 Grain length

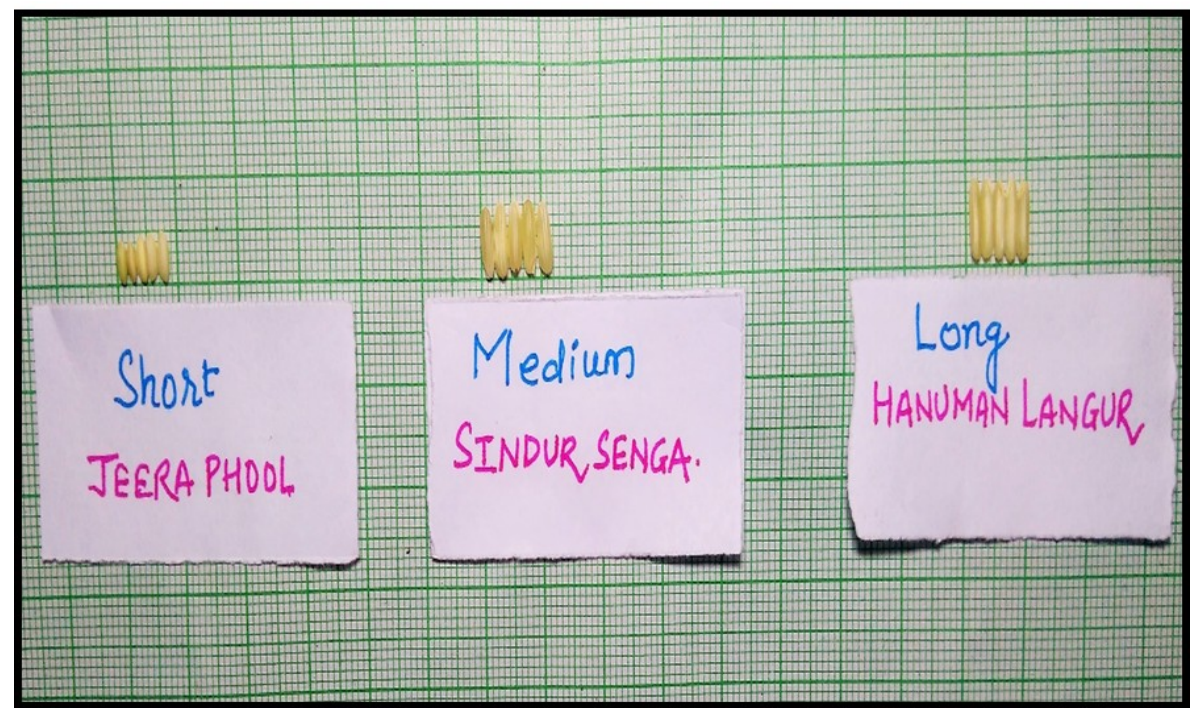

Figure 2 Decorticated Grain length

environment and "controlled by additive gene action (Panse, 1957)". Therefore, these characters could be enhanced through direct selection or progeny selections. None of the characteristic exhibited high heritability with low GA as percent means which show the absence of non-additive gene action among the studied characters.

\subsection{Descriptive Statistics for various grain quality parameters}

"Descriptive statistical measures can illustrate a great deal of information about any variable of interest". Descriptive statistics, presenting the measures of central tendency and measure of variations for all the traits are given in table 4.Grain length ranges from $4.84 \mathrm{~mm}$ (Bhaniya) to $12.66 \mathrm{~mm}$ (Parmal) with an average of $8.30 \mathrm{~mm}$ (Figure 1), grain width ranges from $1.79 \mathrm{~mm}$ (Lalmati) to $3.97 \mathrm{~mm}$ (Danteshwari) with an average of $2.80 \mathrm{~mm}$. L/B ratio of grain ranges from $1.76 \mathrm{~mm}$ (Bhaniya) to $5.43 \mathrm{~mm}$ (Lanji) with an average of $3.03 \mathrm{~mm}$. Brown rice length ranges from $4.00 \mathrm{~mm}$ (Bhaniya) to $8.00 \mathrm{~mm}$ (R-RF-75) with an average of $6.39 \mathrm{~mm}$ (Figure 2). Brown rice breadth ranges from $1.60 \mathrm{~mm}$ (Lalmati) to $3.01 \mathrm{~mm}$ (Chapti gurmatia) with an average of $2.35 \mathrm{~mm}$. Brown rice $\mathrm{L} / \mathrm{B}$ ratio ranges from $1.57 \mathrm{~mm}$ (Bhaniya) to $4.38 \mathrm{~mm}$ (Lalmati) with an average of $2.57 \mathrm{~mm}$. Thousand grain weight ranges from $8.70 \mathrm{gm}$ (Ram jira) to $47.40 \mathrm{gm}$ (Hathipanjra) with an average of $22.86 \mathrm{gm}$. 


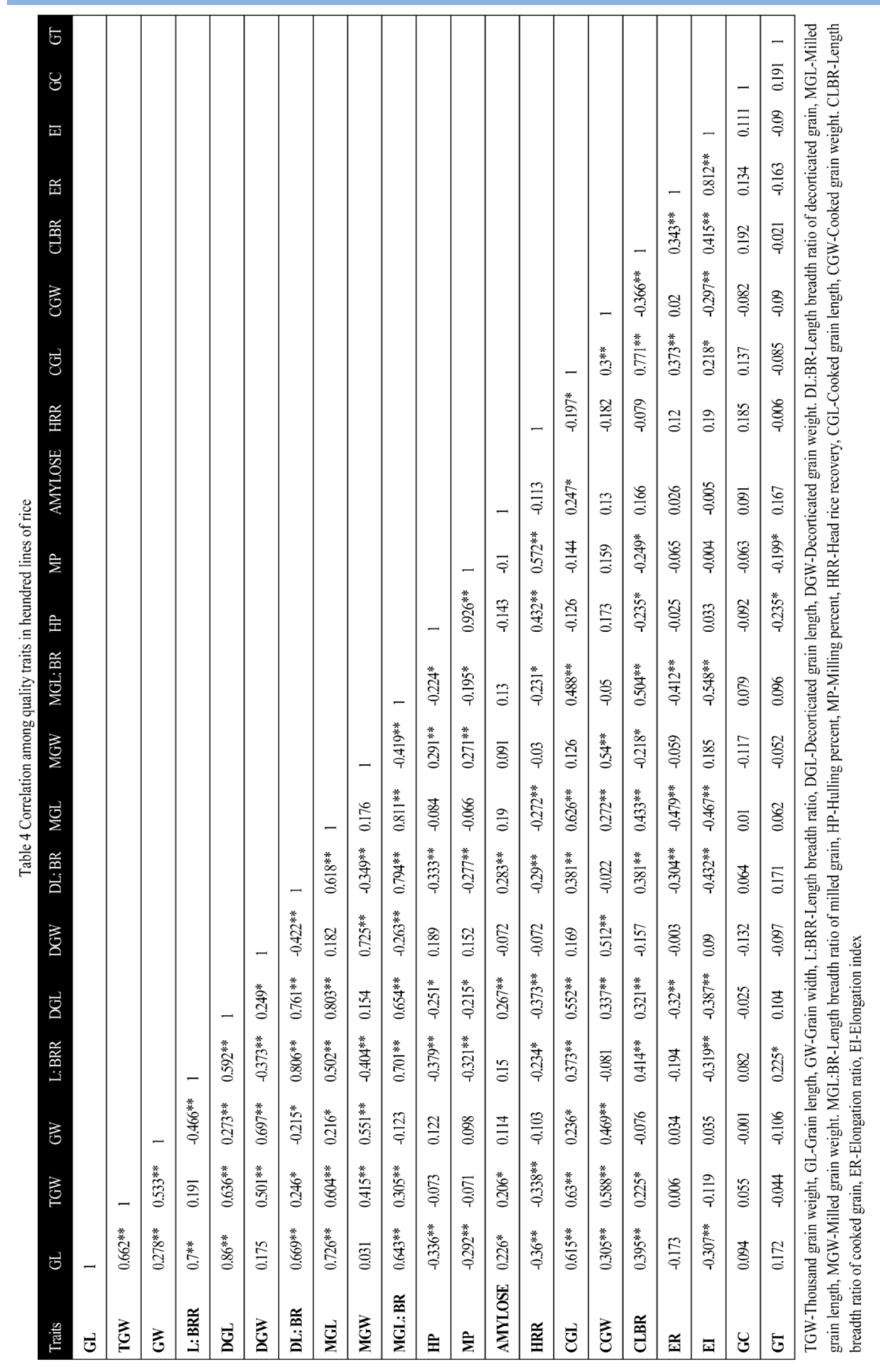

Journal of Experimental Biology and Agricultural Sciences http://www.jebas.org 
Table 5 DUS based classification of grain shape of Rice Landraces

\begin{tabular}{|c|c|}
\hline State & Genotypes \\
\hline $\begin{array}{l}\text { Short Slender } \\
(<6.0 \text { and }>3.0)\end{array}$ & Bawati chudi, Parmal \\
\hline $\begin{array}{l}\text { Short Bold } \\
(<6.0 \text { and }<2.5)\end{array}$ & $\begin{array}{l}\text { Elayachi, Bhulau, Elayachi, Kanak, JiraKoudi dhull, Paltu, Unknown, Angur Guchcha, Shyam jira-,1Lokti Machhi, } \\
\text { Tulsi Phool, Asam Chudi, Tebaroo Mundaria, Kadam Phool, Dokra Dokri, Lahsun Bhog, Jal Ponga, Bhaniya, Muni } \\
\text { Bhog, Jhitpiti, Bokra Mundi, Jeera Phool, Danwar, Karhani, Jou Phool-2, Bhejari, Peelee Luchai, Bagri, Karhani, } \\
\text { Bhainsa Mundariya, Ama jhopa, Ama Dhul, Tulsi Mongra, Bylao,WR99, Luchai(A), Bisni-I, Nagina-22, Tulsi } \\
\text { Mala, Tulsi manjari, Jou Phool, Bhainsa Punchhi, Ram Jira, Satha dhan, BD kankari bija, Sonapan, Cross 116, Sau } \\
\text { pankhi, Baisur, Bhanta Phool-1, Kanak, Swarna, Sindur senga }\end{array}$ \\
\hline $\begin{array}{l}\text { Medium Slender } \\
(<6.0 \text { and } 2.5-3.0)\end{array}$ & $\begin{array}{l}\text { Kalajira, Laloo-14, Laxmi Bhog, Bakal, Mehapal, Hardi chudi, CR-1014, Farsa Phool, IR64, Basigal(ii), Ichchawati, } \\
\text { Padari dhan IV }\end{array}$ \\
\hline $\begin{array}{l}\text { Long Slender } \\
(>6.0 \text { and }>3.0)\end{array}$ & Lanji, Lalmati \\
\hline $\begin{array}{l}\text { Long Bold } \\
(>6.0 \text { and }<3.0)\end{array}$ & $\begin{array}{l}\text { Koto, Kotte (II), Chapti gurmatia, Moroberekan, Baila Aankhi, Kating, Kohaka, Bodi, E-1702, Farsa Phool, Banda, } \\
\text { Bhamasur, Nariyal Chudi, Budhiya wako, Deshi lal dhan, IR 42253, Dokrae mechha, IGKV R1, MTU-1010, Danteshwari }\end{array}$ \\
\hline $\begin{array}{l}\text { Basmati type } \\
(>6.61 \text { and }>3.0)\end{array}$ & Chiko, Silipat, Bhejari, Raja Bangla, R-RF-75, Jalle, Roti, Khatia pati, Hathi panjra, Hunuman Langur, R-RF-75 \\
\hline
\end{tabular}

DUS based grain shape classification of all genotypes are given in table 5 . Two genotypes (Bawati chudi and Parmal) have short slender type grain characteristics whereas 53 genotypes have short bold type grains (Table 5). Twelve landraces have medium slender type grain characteristics. Out of 100 rice genotypes, Lanji, Lalmati has long slender type grain feature whereas 20 genotypes has long bold type grain characteristics and 11 lines showed basmati type grain shape.

Kernel length after cooking ranges from $5.00 \mathrm{~mm}$ (Bhualu) to 11.00 $\mathrm{mm}$ (MTU-1010) with an average of $7.71 \mathrm{~mm}$. Kernel breadth after cooking ranges from $2.20 \mathrm{~mm}$ (Ichchawati) to $3.70 \mathrm{~mm}$ (Farsaphool) with an average of $2.99 \mathrm{~mm}$. Kernel $\mathrm{L} / \mathrm{B}$ ratio after cooking ranges from $1.47 \mathrm{~mm}$ (Bhulau) to $3.92 \mathrm{~mm}$ (Bhamasur) with an average of $2.60 \mathrm{~mm}$. Elongation ratio ranges from 1.00 (Amadhul) to 2.21 (Unknown) with an average of 1.48. Elongation index ranges from 0.59 (Lalmati) to 1.72 (Elayachi) with an average of 1.11 .

Hulling percent ranges from $43.45 \%$ (Dokrae mechcha) to $96.86 \%$ (Cross 116) with an average of $75.77 \%$. Total 38 genotypes showed $>80 \%$ hulling percent among the all genotypes. Milling percentage ranges from $37.35 \%$ (Laxmi Bhog) to $90.92 \%$ (Byalo) with a mean of $67.96 \%$. High head rice yield is one of the most important criteria for measuring milled rice quality. Head rice recovery percent ranges from $10.16 \%$ (Karhani) to $76.08 \%$ (Cross 116 ) with an average of
$41.33 \%$. "Genotypes having high hulling percent and HRR percent could be utilized fordevelopment of good quality rice variety".

Gelatinization temperature (GT) is an extent of time and temperature necessary for cooking of rice grains which is assessed based on alkali spreading value (ASV). The ASV varied over a wide range from 1 to 7 (Figure 4).Total 15 genotypes have intermediate type alkali spreading value (4-5 scale) which has $70-74^{\circ} \mathrm{C}$ gelatinization temperature. Total 85 genotypes showed high ASV (6-7) which had low gelatinization temperature.

Landrace Hardichudi $(28.00 \mathrm{~mm})$ had lowest gel consistency whereas most of the landraces had highest $(100 \mathrm{~mm})$ gel consistency with an average of $92.32 \mathrm{~mm}$. Gel consistency defines the hardness or softness of cooked rice. Soft and medium gel consistency types are generally chosen by consumers at different regions. In present investigation, total 2 genotypes had intermediate type $(40 \mathrm{~mm}-$ $60 \mathrm{~mm}$ ) gel consistency (Figure 5). Amylose content is considered as a prime determinant of cooking quality with GT and GC in rice. The amount of amylose defines how sticky the rice grain will be when cooked. Amylose content ranges from $5.08 \%$ (Roti) to $40.69 \%$ (Baisur) with an average of $19.11 \%$. About 28 genotypes has intermediate amylose content (20-25\%) (Figure 3). "Varieties with intermediate amylose content are generally most chosen in Indian

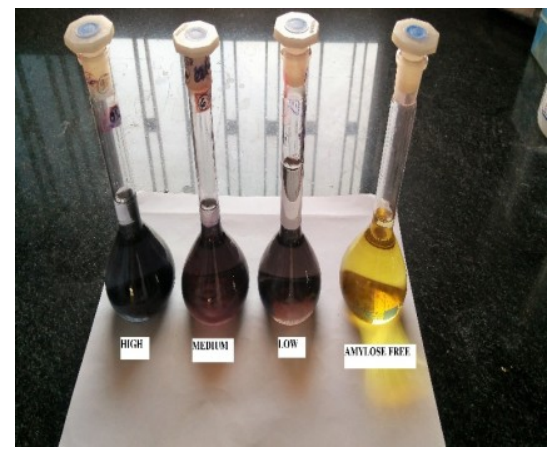

Figure 3 Amylose testing

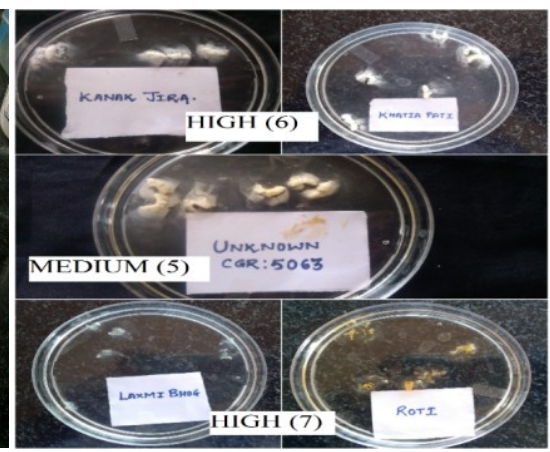

Figure 4: Degree of Alkali digestion in rice genotypes

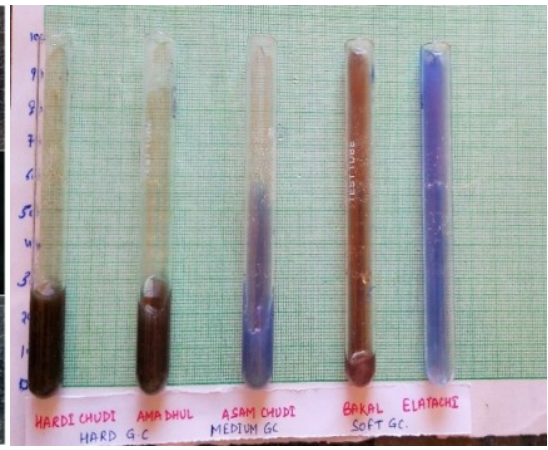

Figure 5 Gel Consistency

Journal of Experimental Biology and Agricultural Sciences http://www.jebas.org 
conditions since they look fluffy and dry retaining their soft texture even after cooling".

Among the quality traits, highest standard deviation was found for gel consistency followed by head rice recovery percent, hulling percent and thousand grain weight. Standard deviation provides a reliable estimate of the degree to which the numbers in the variable deviate from the mean. "Thus, the standard deviation is truly a standard measure of variability that applies to any distribution, regardless of the unit of measure used (Larson \& Farber, 2002). If the standard deviation is very small, scores are not scattered far from the mean. The larger the standard deviation, the more widely scattered are values in the distribution (McHugh, 2003)".

\subsection{Correlation among grain quality traits}

"Quality characters are complex in nature, which is influenced by the environment. Grain quality traits are interrelated among themselves which in turn decides the final cooking and eating characteristics. So the present experiment was undertaken to study the association among different quality attributing traits in rice".

In the present investigation, strong and highly significant positive correlation between grain length and thousand grain weight $(\mathrm{r}=0.662 * *)$ was found (Table 4). Length of the grain was as well positively and significantly correlated with amylose content $\left(\mathrm{r}=0.226^{* *}\right)$. While for the grain length, the correlation was strong but negative with hulling percent $\left(\mathrm{r}=-0.336^{* *}\right)$, milling percent $\left(-0.292^{* *}\right)$, head rice recovery $\left(\mathrm{r}=-0.36^{* *}\right)$ and elongation index $\left(\mathrm{r}=-0.307^{* *}\right)$ Length of the decorticated grain exhibited strong and positive significant association with thousand grain weight $\left(\mathrm{r}=0.636^{* *}\right)$, whereas decorticated grain width again revealed positive significant correlation with thousand grain weight $\left(\mathrm{r}=0.501^{* *}\right)$. There was a highly significant and positive strong correlation between hulling percent and milled grain width was found $\left(\mathrm{r}=0.291^{* *}\right)$, while hulling percent showed statistically significant but negative correlation with decorticated grain length $(\mathrm{r}=-0.251 *)$.

Head rice recovery showed strong positive and significant correlation with milling percent $\left(\mathrm{r}=0.572^{* *}\right)$ and hulling percent $\left(\mathrm{r}=0.432^{* *}\right)$, while negative correlation of HRR with MLBR $(\mathrm{R}=-$ $\left.0.231^{*}\right)$ may be due to the fact that grains of smaller length generally break less than longer grains during milling. Thus, grain size and shape are closely related to yields of unbroken grain during the process of milling (Jennings et al., 1979). During the milling, the breakage of the kernels is caused due to the stress cracks and it influences the hulling, milling and HRR per cent. The key factors responsible for breaking are variation of rice, management of post-harvest operations, drying conditions and other operational conditions. Suman et al. (2020) also found HRR was negatively associated with the length/breadth ratio of milled rice, which supports the present study.
There was a strong and significant positive correlation between amylose content and thousand grain weight $\left(\mathrm{r}=0.206^{*}\right)$, amylose content also found positively significant correlated with decorticated grain length and decorticate L/B ratio $\left(\mathrm{r}=0.283^{* *}\right)$ amylose content correlated to decorticated grain length was also reported by Rawte \& Saxena (2017). Cooked grain length exhibited positive and strong association with thousand grain weight $\left(\mathrm{r}=0.63^{* *}\right)$. Elongation ratio had strongly positive significant correlation with grain length after cooking $\left(\mathrm{r}=0.373^{* *}\right)$ and decorticated grain length $(0.32 * *)$ grain length after cooking and elongation ratio are reliant as evidenced by the positive significant association between them. Selection of both the characteristic will ultimately improve the mean performance of the interdependent trait similar result was also reported by Rawte \& Saxena (2017). Similarly elongation index showed positive and significant correlation with elongation ratio $\left(0.812^{* *}\right)$ and $\mathrm{L} / \mathrm{B}$ ratio after cooking $\left(0.415^{* *}\right)$. This was in agreement with the findings of Mahalingam (2008) for kernel length after cooking and kernel L/B ratio and Suman et al. (2020) for elongation index and ratio.

\section{Conclusion}

Considering the grain quality traits, studied hundred lines of rice showed ample amount of genetic variability. Hanthi panjra, Dokrae mechha, Parmal, Hanuman langur and Raja Bangla exhibited longest kernel length. Cross-116, Kanak jira and Paltu showed high hulling, milling as well as HRR percentage. Genotype Koto, Karhani and Unknown (CGR: 5036) was found to have intermediate gel consistency and gelatinization temperature while it also exhibit low content of amylose. Aforesaid genotypes can be used good quality rice development. Traits like, thousand grain weight, Grain length, Head Rice Recovery, Amylose content and Gel consistency show high PCV, GCV, $\mathrm{h}^{2}$ and GA indicates that the traits were simply inherited in nature and controlled by few major genes or possessed additive gene effect, therefore these characters can be enhanced through direct selection.

\section{Conflicts of interest}

All authors declare there is no conflict of interest among them.

\section{References}

Abdala AJ, Bokosi JM, Mwangwela AM, Mzengeza TR (2016) Correlation and path co-efficient analysis for grain quality traits in F1 generation of rice (Oryza sativa L.). Journal of Plant Breeding and Crop Science 8:109-116.

Anacleto R, Cuevas PR, Jimenez R, Llorente C, Nissila E, Henry R Sreenivasulu N (2015) Prospects of breeding high-quality rice using post-genomic tools. Theoretical and Applied Genetics 128: 1449-1466. 
Babu VR, Shreya K, Dangi K S, Usharani G, Nagesh P (2012) Genetic variability studies for qualitative and quantitative traits in popular rice (Oryza sativa L.) hybrids of India. International Journal of Scientific and Research Publications 2: 1-5.

Burton GW (1952) Quantitative inheritance in grasses. 6th International Grassland Congress 1:277-283.

Cuevas RP, de Guia A, Demont M (2017) Developing a framework of gastronomic systems research to unravel drivers of food choice. International Journal of Gastronomy and Food Science 9:88-99.

Devi KR, Chandra SB, Lingaiah N, Hari Y, Venkanna V (2017) Analysis of variability, correlation and path coefficient studies for yield and quality traits in rice (Oryza sativaL.). Agricultural Science Digest 37(1): 1-9.

Devi KR, Parimala K, Venkanna V, Lingaiah N, Hari Y, Chandra SB (2016) Estimation of variability for grain yield and quality traits in rice (Oryza sativaL.). International Journal of Pure and Applied Biosciences 4(2): 250-255.

Dhanwani RK, Sarawagi AK, Solanki A, Tiwari JK (2013) Genetic variability analysis for various yield attributing and quality traits in rice (Oryza sativaL.). The Bioscan 8(4): 1403-1407.

DRR (2014) Laboratory manual on rice grain quality. Manual of ICAR-DRR, Rajendranagar, Hyderabad.

Hanson WD, Robinson H F, Comstock RE (1956) Biometrical studies of yield in segregating population Korean Lespandeza. Journal of Agrobiology 48: 268-272.

Jamuna P, Megha CP, Divya R(2019) Physico-Chemical and Cooking Properties of Selected Rice Varieties. Acta Scientific Nutritional Health 3: 23-30.

Jennings PR, Coffman WR, Kauffman HE (1979) Rice improvement, international rice research institute, Los Banos, Philippines.

Johnson HW, Robinson HF, Comstock RE (1955) Estimation of genetic and environmental variability in soybean. Journal of Agrobiology 47: 314-318.

Juliano BO (1971) A simplified assay for milled rice amylose. Cereal Science Today 16: 334-340.

Kiani G, Nematzadeh G (2012) Correlation and Path Coefficient Studies in F2 Populations of Rice. Notulae Scientia Biologicae 4:124-127.
Larson R,Farber B (2002) Elementary statistics: Picturing the world (2nd ed.). Upper Saddle River, NJ: Prentice Hall.

Little RR, Hilder GB,Dawson EH (1958) Differential effect of dilute alkali on 25 varieties of milled white rice. Cereal Chemistry 35: 111-126.

Mahalingam A (2008) Genetic analysis of yield, grain quality and blast resistance in rice (Oryza sativa L.) through North Carolina Design II. M.Sc., (Ag.) Thesis (Unpubl.) submitted to TNAU, Coimbatore.

Maneerattanarungroj P, Jermklang P, Kongsook B, Maneerattanarungroj P (2015) Diversity of Grains of Rice Landraces of Northeastern Thailand. International journal of Biological and Chemical Science 3: 317-321.

McHugh ML (2003) Descriptive Statistics, Part II: Most commonly used descriptive statistics. Journal for Specialists in Pediatric Nursing 8: 111-116.

My NHD, Demont M, Van Loo EJ, de Guia A, Rutsaert P, Tuan $\mathrm{TH}$ (2018) What is the value of sustainably produced rice? Consumer evidence from experimental auctions in Vietnam. Food Policy 79:283-296.

Panse VG (1957) Genetics of quantitative characters in relation to plant breeding. Indian Journal of Genetics 17: 318-328.

Panse VG, Sukhatme PV (1967) Statistical methods for agricultural workers (2nd Ed) ICAR publications, New Delhi, India.

Rathi S, Yadav RNS, Sarma RN (2010) Variability in Grain Quality Characters of Upland Rice of Assam, India. Rice Science 17: 330-333.

Rawte S, Saxena RR (2017) Correlation and path coefficient analysis of quality traits in selected rice (Oryza sativa L.) germplasm accessions. International Journal of Chemical Studies 5:547-551.

Roychowdhury R, Tah J (2011) Evaluation of genetic parameters for agro-metrical characters in Carnation genotypes. African Crop Science Journal 19: 183-188.

Suman K, Madhubabu P, Rathod R, Rao DS, Rojarani A, Prashant S, Subbarao LV, Ravindrababu V, Neeraja CN (2020) Variation of grain quality characters and marker-trait association in rice (Oryza sativa L.). Journal of Genetics 99:15-24. 